\title{
Determination of the Elements Composition in Sempervivum tectorum L. from Bulgaria
}

\author{
Galia Gentscheva ${ }^{1,2}$, Irina Karadjova ${ }^{3}$, Poli Radusheva ${ }^{4}$, Stefka Minkova ${ }^{4}$, Krastena Nikolova ${ }^{4, *}$, \\ Yoana Sotirova ${ }^{5}$ (D) Ina Yotkovska ${ }^{1}$ and Velichka Andonova ${ }^{5, * \mathbb{D}}$
}

\section{check for} updates

Citation: Gentscheva, G.; Karadjova, I.; Radusheva, P.; Minkova, S.;

Nikolova, K.; Sotirova, Y.; Yotkovska,

I.; Andonova, V. Determination of the

Elements Composition in

Sempervivum tectorum $\mathrm{L}$. from

Bulgaria. Horticulturae 2021, 7, 306.

https://doi.org/10.3390/

horticulturae7090306

Academic Editors: Dasha Mihaylova and Aneta Popova

Received: 12 August 2021

Accepted: 9 September 2021

Published: 12 September 2021

Publisher's Note: MDPI stays neutral with regard to jurisdictional claims in published maps and institutional affiliations.

Copyright: (c) 2021 by the authors. Licensee MDPI, Basel, Switzerland. This article is an open access article distributed under the terms and conditions of the Creative Commons Attribution (CC BY) license (https:// creativecommons.org/licenses/by/ $4.0 /)$.
1 Department of Chemistry and Biochemistry, Medical University of Pleven, 5800 Pleven, Bulgaria; gentscheva@mu-pleven.bg (G.G.); ina.iotkovska@mu-pleven.bg (I.Y.)

2 Institute of General and Inorganic Chemistry, Bulgarian Academy of Sciences, 1113 Sofia, Bulgaria

3 Faculty of Chemistry and Pharmacy, University of Sofia, 1164 Sofia, Bulgaria; Karadjova@chem.uni-sofia.bg

4 Department of Physics and Biophysics, Medical University of Varna, 9000 Varna, Bulgaria; radusheva@mu-varna.bg (P.R.); stefka.minkova@yahoo.com (S.M.)

5 Department of Pharmaceutical Technologies, Medical University of Varna, 9000 Varna, Bulgaria; Yoana.Sotirova@mu-varna.bg

* Correspondence: kr.nikolova@abv.bg (K.N.); velichka.andonova@mu-varna.bg (V.A.); Tel.: +35-988-860-3272 (K.N.); +35-989-783-2753 (V.A.)

Abstract: Sempervivum tectorum L. is an evergreen plant with fleshy blue-green leaves forming a rosette. The plant is well-known in alternative medicine and has been used for thousands of years. Traditionally for medicinal purposes, the plant is used as a juice obtained by simple squeezing of fresh plants leaves. The total content of $\mathrm{Ca}, \mathrm{K}, \mathrm{Na}, \mathrm{Mg}, \mathrm{Mn}, \mathrm{Fe}, \mathrm{Zn}, \mathrm{Cu}, \mathrm{Co}, \mathrm{Al}, \mathrm{V}, \mathrm{Cr}, \mathrm{Ni}, \mathrm{Mo}, \mathrm{Ba}$, $\mathrm{Pb}, \mathrm{Cd}, \mathrm{Hg}$, As, and $\mathrm{Tl}$ in plant leaves of Sempervivum tectorum $\mathrm{L}$. sampled from different habitats in Bulgaria was determined after microwave digestion and measurements by inductively coupled plasma mass spectrometry and flame atomic absorption spectrometry. Furthermore, the bioavailable fraction of essential elements $\mathrm{Ca}, \mathrm{Mg}, \mathrm{Fe}, \mathrm{Mn}$, and $\mathrm{Zn}$ was defined after extraction with a hydrochloric acid solution, mimicking stomach juice. The total element content showed a high bioavailability of essential human health elements, such as $\mathrm{Ca}, \mathrm{Mg}, \mathrm{Fe}$, and $\mathrm{Zn}$. Additionally, essential and toxic elements concentrations were quantified in a fresh juice, obtained by squeezing from plant leaves, as most frequently used in folk medicine. The results obtained demonstrated high concentrations of $\mathrm{K}$, $\mathrm{Mg}, \mathrm{Ca}, \mathrm{Zn}$, and $\mathrm{Cu}$, which could be accepted as an explanation and a further confirmation of the anti-inflammatory action of this plant.

Keywords: Sempervivum tectorum L.; mineral content; bioavailable fraction; heavy metals

\section{Introduction}

There are over 3000 plant species in Bulgaria, of which more than 600 are used for medicinal purposes. Bulgarian herbs contain a high percentage of biologically active substances [1]. They are rich in various chemical compounds: alkaloids, glycosides, saponins, polysaccharides, tannins, flavonoids, coumarins, essential oils, vitamins, and trace elements. The pharmacological and medicinal action and application of Bulgarian herbs has been an important topic and subject of many studies. One of the most outstanding achievements of the Bulgarian pharmaceutical industry was the creation of the medicinal preparation "Nivalin" by Prof. D. Paskov. The active substance of which is the alkaloid galantamine, extracted from Leucojum aestivum L. [2]. Most of the achievements of contemporary medical science are based on bioactive compounds extracted from medicinal plants [3].

Sempervivum tectorum L. (synonym: Sempervivum tectorum var. arvernense (Lecoq \& Lamotte) Zonn., Sempervivum tectorum var. andreanum (Wale) O.Bolòs \& Vigo) belongs to a large family of Crassulaceae with crassulacean acid metabolism, native to the mountains of southern Europe and cultivated in the whole of Europe. 
Sempervivum tectorum L. (houseleek) is an evergreen plant with fleshy blue-green leaves forming a rosette, which grows on dry to fresh sandy soils and in sunny to semisunny places. The plant is well-known in folk medicine and has been used for thousands of years.

In recent years, researchers have focused on studies of the characterization of the bioactive ingredients of this plant and their ability to restore liver function [4], their antioxidant properties [5], the potential for wound healing [6], anti-inflammatory action, and analgesic and detoxicating properties [7-9]. Most of these properties of Sempervivum tectorum L. are connected with phenolic compounds identified in fresh juices squeezed from plant leaves [10,11]. However, according to the author's knowledge, despite of the numerous uses of Sempervivum tectorum L. in folk medicine, it remains poorly known from the viewpoint of systematic investigations into trace element content, element bioavailability, and correlation between essential element content and antioxidant activity.

The trace element content is an essential characteristic of any plant. However, there are no such data for Sempervivum tectorum L., neither for environmental safety, nor the effect on human health. The objective of this study was to investigate the level of the elements $\mathrm{Ca}$, $\mathrm{K}, \mathrm{Na}, \mathrm{Mg}, \mathrm{Mn}, \mathrm{Fe}, \mathrm{Zn}, \mathrm{Cu}, \mathrm{Co}, \mathrm{Al}, \mathrm{V}, \mathrm{Cr}, \mathrm{Ni}, \mathrm{Mo}, \mathrm{Ba} . \mathrm{Pb}, \mathrm{Cd}, \mathrm{Hg}$, and As as total content in plant samples of Sempervivum tectorum L. obtained from different sampling sites; natural and affected at different levels by human activities. The urban soil (A) is from an urban park close to center of the city, and the fertilized soil (C) is from land used for agriculture purposes for many years. The rural soil (B) and mountain soil (D) might be accepted as natural; however, with varying composition. The bioavailable fraction of essential elements $\mathrm{Ca}, \mathrm{Mg}, \mathrm{Fe}, \mathrm{Mn}$, and $\mathrm{Zn}$, defined according to a standard procedure for element migration in hydrochloric acid that mimics food digestion processes in the stomach, was quantified. Additionally, $\mathrm{K}, \mathrm{Ca}, \mathrm{Mg}, \mathrm{Na}, \mathrm{Fe}, \mathrm{Mn}, \mathrm{Zn}, \mathrm{Al}, \mathrm{Cu}$, and $\mathrm{Cr}$ were determined in the freshly squeezed juice from plant leaves, as directly used in folk medicine against ear pain.

\section{Materials and Methods}

Plant Material. S. tectorum plants were from different habitats, grown on city soils (A), village soils (B), fertilized soils (C), and mountain soils (D). The leaves of the plants were removed, thoroughly washed with deionized water to remove all possible external contaminants, and used immediately for:

(i). the preparation of fresh juice after squeezing;

(ii). the preparation of a fresh homogeneous sample mix after milling for the determination of bioavailable fraction;

(iii). the preparation of dry mass after oven drying to a constant weight at $40{ }^{\circ} \mathrm{C}$ and homogenization by careful grinding.

Sample preparation before analysis:

Reagents: $67 \% \mathrm{HNO}_{3}$ (supra pure, Merck, Darmstadt Germany); $30 \% \mathrm{H}_{2} \mathrm{O}_{2}$ (supra pure, Merck, Darmstadt Germany); 37\% HCl (p.a. Sigma-Aldrich, Darmstadt Germany).

\subsection{Determination of Total Content of Elements}

A dry sample of around $0.5 \mathrm{~g}$ was weighed in Teflon vessels of a microwave digestion system, $6 \mathrm{~mL} 67 \% \mathrm{HNO}_{3}$ and $2 \mathrm{~mL} 30 \% \mathrm{H}_{2} \mathrm{O}_{2}$ were added, and samples were left overnight. Microwave digestion was performed for $20 \mathrm{~min}$ : $10 \mathrm{~min}$ to reach $180{ }^{\circ} \mathrm{C}$ and $10 \mathrm{~min}$ maintained at this temperature. After cooling, samples were transferred to a $50 \mathrm{~mL}$ volumetric flask and diluted up to the mark with deionized water. A blank sample was passed through the whole analytical procedure.

\subsection{Determination of Bioavailable Fraction in Fresh Leaves}

A sample of $2.0 \mathrm{~g}$ of fresh leaves was milled with $50 \mathrm{~mL}$ deionized water in a plastic container. After that, $50 \mathrm{~mL} 0.14 \mathrm{~mol} \mathrm{~L}^{-1} \mathrm{HCl}$ were added, and the mixture was shaken for at least $1 \mathrm{~min}$. The suspension was left for several minutes to settle, and the $\mathrm{pH}$ of the clear supernatant was measured. If the $\mathrm{pH}$ was above $1.5,2 \mathrm{~mol} \mathrm{~L}^{-1} \mathrm{HCl}$ solution 
was added drop-wise while mixing until the $\mathrm{pH}$ reached values between 1.0 and 1.5. The container was closed and agitated at $37 \pm 2{ }^{\circ} \mathrm{C}$ for $1 \mathrm{~h}$. After that, the suspension was left for a further $1 \mathrm{~h}$ at $37 \pm 2{ }^{\circ} \mathrm{C}$. The mixture was protected from daylight. The solid matter was separated by centrifugation and, if necessary, filtrated through a membrane filter $(0.22 \mu \mathrm{m})$ to remove all solid particles. The separation should be completed as soon as possible after completing the standing time; centrifuging should take no longer than $10 \mathrm{~min}$. Next, the obtained solution was evaporated on a hot plate to $2-3 \mathrm{~mL}, 3 \mathrm{~mL}$ of conc. $\mathrm{HNO}_{3}$ was added for digestion of the organic components, and, finally, the sample was quantitatively transferred to a $25 \mathrm{~mL}$ flask and made up with deionized water [12].

\subsection{Determination of Elements in Juice Obtained by Squeezing of Fresh Leaves}

A sample of $2.0 \mathrm{~g}$ juice (obtained after filtration of fresh juice through a $0.22 \mu \mathrm{m}$ membrane filter) was transferred in a glass beaker and treated with $1 \mathrm{~mL} 67 \% \mathrm{HNO}_{3}$ on a hot plate. After $1 \mathrm{~h}$, the solution was cooled and diluted in a $10 \mathrm{~mL}$ volumetric flask with distilled water.

Apparatus for quantitative measurement of chemical elements:

Flame atomic absorption spectrometry: The content of $\mathrm{Fe}, \mathrm{K}, \mathrm{Mn}, \mathrm{Mg}, \mathrm{Na}$, and $\mathrm{Zn}$ was measured by flame atomic absorption spectrometry (Thermo Electron-SOLAAR Mkll M5 series, UK) in an air/acetylene flame under optimized instrumental parameters. The content of $\mathrm{Ca}$ was measured in $\mathrm{N}_{2} \mathrm{O}$ /acetylene flame, using the same instrument. Stock standard solutions of $\mathrm{Ca}, \mathrm{Fe}, \mathrm{K}, \mathrm{Mn}, \mathrm{Mg}, \mathrm{Na}$, and $\mathrm{Zn}\left(1.000 \mathrm{~g} \mathrm{~L}^{-1}\right.$ (Merck)) were used for the preparation of diluted working standards.

Inductively coupled plasma mass spectrometry: The content of $\mathrm{As}, \mathrm{Al}, \mathrm{Ba}, \mathrm{Cd}, \mathrm{Co}, \mathrm{Cr}$, $\mathrm{Cu}, \mathrm{Hg}, \mathrm{Mo}, \mathrm{Ni}, \mathrm{Pb}$, and $\mathrm{V}$ was measured by ICP-MS using an inductively coupled plasma mass spectrometer "X SERIES 2"-Thermo Scientific, USA with a 3 channel peristaltic pump; concentric nebulizer; Peltier-cooled spray chamber $\left(4^{\circ} \mathrm{C}\right)$; $\mathrm{Xt}$ interface option; $\mathrm{Ni}$ cones. Optimized instrumental parameters: forward plasma power of $1400 \mathrm{~W}$; plasma gas flow $13 \mathrm{~L} \mathrm{~min} / \mathrm{L}$; nebulizer flow $0.85 \mathrm{~L} / \mathrm{min}$; dwell time $30 \mathrm{~ms}$; measurements $3 \times 30$ scans. Stock standard solutions: multielement standard solution 5 for ICP (TraceCERT ${ }^{\circledR}$, Merck), $1000 \mathrm{mg} / \mathrm{L}$ As (Fluka, Sigma-Aldrich) and $1000 \mathrm{mg} / \mathrm{L} \mathrm{Hg}$ (Fluka, Sigma-Aldrich) were used for the preparation of diluted working standard solutions for calibration of ICP-MS.

The accuracy of the analytical procedure used was validated by the analysis of certified reference material NIST SRM 1573a Tomato leaves. The very good agreement with the certified values and the recoveries above $95 \%$ achieved for all certified elements confirmed the reliability of the results obtained for total element contents (see Table 1). Limit of detection and limit of quantification was calculated for each element based on standard deviation of blanks sample for the respective procedures using $3 \sigma$ criterium (LOD) and $10 \sigma$ criterium (LOQ). Calculated values for LOD and LOQ are presented in Table 1.

\subsection{Statistical Analysis}

Data for the concentrations of chemical elements were processed to obtain the mean and standard deviation of the mean (SD). One-way analysis of variance, followed by a Student's $t$-test was used to compare the mean values. A value of $p<0.05$ was considered to be statistically significant. 
Table 1. Results and recoveries for chemical element contents $(\mathrm{mg} / \mathrm{kg}$ ) determined in NIST SRM 1573a Tomato leaves (three parallel determinations).

\begin{tabular}{|c|c|c|c|c|}
\hline $\begin{array}{l}\text { Element, } \\
\mathrm{mg} / \mathrm{kg}\end{array}$ & $\begin{array}{l}\text { Determined } \\
\text { (Mean } \pm \text { sd) }\end{array}$ & $\begin{array}{c}\text { Certified } \\
(\text { Mean } \pm \text { sd) }\end{array}$ & $\begin{array}{l}\text { Recovery, \% } \\
\text { (Mean) }\end{array}$ & $\begin{array}{c}\mathrm{LOQ} / \mathrm{LOD}, \\
\mathrm{mg} / \mathrm{kg}\end{array}$ \\
\hline Al (ICP-MS) & $594 \pm 4$ & $598.4 \pm 7.1$ & 99.3 & $0.10 / 0.35$ \\
\hline As (ICP-MS) & $0.1088 \pm 0.056$ & $0.1126 \pm 0.0024$ & 96.6 & $0.02 / 0.06$ \\
\hline Cd (ICP-MS) & $1.456 \pm 0.016$ & $1.517 \pm 0.027$ & 96 & $0.02 / 0.05$ \\
\hline $\mathrm{Ca}$ (FAAS) & $49,441 \pm 342$ & $50,450 \pm 550$ & 98 & $2 / 6$ \\
\hline Cr (ICP-MS) & $1.92 \pm 0.04$ & $1.988 \pm 0.034$ & 96.6 & $0.05 / 0.15$ \\
\hline Co (ICP-MS) & $0.5588 \pm 0.021$ & $0.5773 \pm 0.0071$ & 96.8 & $0.02 / 0.06$ \\
\hline $\mathrm{Cu}$ (ICP-MS) & $4.56 \pm 0.11$ & $4.70 \pm 0.14$ & 97 & $0.1 / 0.3$ \\
\hline $\mathrm{Fe}$ (FAAS) & $363.8 \pm 2.1$ & $367.5 \pm 4.3$ & 99 & $3 / 10$ \\
\hline Mn (FAAS) & $243.8 \pm 9.3$ & $246.3 \pm 7.1$ & 99 & $3 / 10$ \\
\hline Hg (ICP-MS) & $0.0329 \pm 0.0043$ & $0.0341 \pm 0.0015$ & 96.5 & $0.02 / 0.06$ \\
\hline Ni (ICP-MS) & $1.536 \pm 0.031$ & $1.582 \pm 0.041$ & 97.1 & $0.02 / 0.05$ \\
\hline K (FAAS) & $26,490 \pm 312$ & $26,760 \pm 480$ & 99 & $5 / 15$ \\
\hline $\mathrm{Na}$ (FAAS) & $134.3 \pm 2.5$ & $136.1 \pm 3.7$ & 98,7 & $5 / 15$ \\
\hline V (ICP-MS) & $0.809 \pm 0.042$ & $0.835 \pm 0.034$ & 96.9 & $0.02 / 0.06$ \\
\hline Zn (FAAS) & $30.02 \pm 0.56$ & $30.94 \pm 0.55$ & 97 & $1 / 3$ \\
\hline
\end{tabular}

\section{Results}

The profile of chemical elements in plants depends on the geochemical characteristics of the soil [13] and on the ability of plants to selectively accumulate minerals essential for their growth. For given plants, the content of mineral and trace elements is characteristic and will be affected by different factors, such as the physical and chemical properties of the soil, application of natural and artificial fertilizers, and climatic conditions of the region. The results obtained for the total content of elements in Sempervivum tectorum L. are presented in Tables $2-4$.

Table 2. Essential (basic) element contents in dry samples.

\begin{tabular}{|c|c|c|c|c|c|c|c|}
\hline & $\begin{array}{c}\mathrm{K} \\
\mathrm{g} \mathrm{kg}^{-1}\end{array}$ & $\begin{array}{c}\mathrm{Ca} \\
\mathrm{g} \mathrm{kg}^{-1}\end{array}$ & $\begin{array}{c}\mathrm{Mg}_{\mathrm{g} \mathrm{kg}^{-1}}\end{array}$ & $\begin{array}{c}\mathrm{Na} \\
\mathrm{mg} \mathrm{kg}^{-1}\end{array}$ & $\begin{array}{c}\mathrm{Fe} \\
\mathrm{mg} \mathrm{kg}^{-1}\end{array}$ & $\begin{array}{c}\mathrm{Mn}_{\mathrm{mg} \mathrm{kg}} \\
\mathrm{mg}^{-1}\end{array}$ & $\underset{\mathrm{mg} \mathrm{kg}^{-1}}{\mathrm{Zn}}$ \\
\hline \multicolumn{8}{|c|}{ city soils (A), number of plant samples-4 } \\
\hline mean & 18.0 & 107 & 10.6 & 93.6 & 325 & 35.4 & 49.2 \\
\hline $\min$ & 9.36 & 102 & 4.39 & 16.4 & 188 & 13.9 & 45.1 \\
\hline $\max$ & 29.9 & 115 & 12.3 & 234.9 & 398 & 65.4 & 51.7 \\
\hline \multicolumn{8}{|c|}{ village soils (B), number of plant samples-5 } \\
\hline mean & 11.1 & 116 & 11.6 & 206 & 384 & 30.7 & 79.0 \\
\hline $\min$ & 7.59 & 84.7 & 7.71 & 176 & 328 & 17.4 & 42.2 \\
\hline $\max$ & 12.9 & 132 & 18.2 & 230 & 491 & 50.9 & 135 \\
\hline \multicolumn{8}{|c|}{ fertilized soils (C), number of plant samples- 4} \\
\hline mean & 26.3 & 66.2 & 5.97 & 74.4 & 358 & 273 & 30.5 \\
\hline $\min$ & 10.7 & 60.7 & 3.4 & 67.2 & 243 & 102 & 26.7 \\
\hline $\max$ & 31.4 & 103 & 7.81 & 112 & 427 & 283 & 44.8 \\
\hline \multicolumn{8}{|c|}{ mountain soils (D), number of plant samples-4 } \\
\hline mean & 15.7 & 61.0 & 5.68 & 125 & 247 & 12.1 & 29.2 \\
\hline $\min$ & 7.21 & 57.3 & 3.84 & 102 & 197 & 10.5 & 25.5 \\
\hline $\max$ & 21.3 & 85.1 & 10.5 & 131 & 343 & 18.4 & 37.8 \\
\hline
\end{tabular}


Table 3. The content $(\mathrm{mg} / \mathrm{kg})$ of non-essential elements in dry samples.

\begin{tabular}{|c|c|c|c|c|c|c|c|}
\hline & $\begin{array}{c}\mathrm{Al} \\
\mathrm{mg} \mathrm{kg}^{-1}\end{array}$ & $\begin{array}{c}\text { Co } \\
\mathrm{mg} \mathrm{kg}^{-1}\end{array}$ & $\begin{array}{c}\mathrm{Cu} \\
\mathrm{mg} \mathrm{kg}^{-1}\end{array}$ & $\begin{array}{c}\text { Ba } \\
\mathrm{mg} \mathrm{kg}^{-1}\end{array}$ & $\begin{array}{c}\text { Mo } \\
\mathrm{mg} \mathrm{kg}^{-1}\end{array}$ & $\begin{array}{c}\mathrm{V} \\
\mathrm{mg} \mathrm{kg} \mathrm{kg}^{-1}\end{array}$ & $\begin{array}{c}\mathrm{Cr} \\
\mathrm{mg} \mathrm{kg}^{-1}\end{array}$ \\
\hline \multicolumn{8}{|l|}{$\mathbf{A}$} \\
\hline mean & 23.3 & 0.46 & 7.91 & 51.0 & 0.86 & $<0.02$ & 0.42 \\
\hline $\min$ & 17.0 & 0.32 & 5.63 & 48.5 & $<0.02 *$ & $<0.02$ & 0.37 \\
\hline $\max$ & 32.6 & 0.56 & 11.0 & 53.9 & 2.53 & $<0.02$ & 0.45 \\
\hline \multicolumn{8}{|l|}{ B } \\
\hline mean & 61.1 & 0.39 & 8.12 & 65.4 & 1.96 & 0.10 & 0.63 \\
\hline $\min$ & 38.5 & 0.35 & 5.33 & 50.6 & $<0.02$ & $<0.02$ & 0.49 \\
\hline $\max$ & 99.6 & 0.47 & 10.7 & 74.0 & 5.62 & 0.23 & 0.90 \\
\hline \multicolumn{8}{|l|}{ C } \\
\hline mean & 257.6 & 2.13 & 9.14 & 145.8 & $<0.02$ & 0.05 & 0.76 \\
\hline $\min$ & 94.5 & 1.12 & 7.43 & 85.3 & $<0.02$ & $<0.02$ & 0.37 \\
\hline $\max$ & 301.2 & 2.54 & 12.32 & 153.2 & $<0.02$ & 0.17 & 0.94 \\
\hline \multicolumn{8}{|l|}{ D } \\
\hline mean & 18.5 & 0.24 & 7.32 & 38.7 & $<0.02$ & $<0.02$ & 0.38 \\
\hline $\min$ & 13.4 & 0.05 & 4.91 & 29.5 & $<0.02$ & $<0.02$ & 0.23 \\
\hline $\max$ & 21.3 & 0.32 & 8.94 & 50.4 & $<0.02$ & $<0.02$ & 0.42 \\
\hline
\end{tabular}

Table 4. The total content $(\mathrm{mg} / \mathrm{kg})$ of toxic elements $(\mathrm{Cd}, \mathrm{Pb}, \mathrm{As}, \mathrm{Hg}$, and $\mathrm{Ni})$ in dry samples.

\begin{tabular}{|c|c|c|c|c|c|}
\hline & $\begin{array}{c}\mathrm{Cd} \\
\mathrm{mg} \mathrm{kg}^{-1}\end{array}$ & $\begin{array}{c}\mathrm{Pb} \\
\mathrm{mg} \mathrm{kg}^{-1}\end{array}$ & $\begin{array}{c}\text { As } \\
\mathrm{mg} \mathrm{kg}^{-1}\end{array}$ & $\begin{array}{c}\mathrm{Hg} \\
\mathrm{mg} \mathrm{kg}^{-1}\end{array}$ & $\begin{array}{c}\mathrm{Ni} \\
\mathrm{mg} \mathrm{kg}^{-1}\end{array}$ \\
\hline \multicolumn{6}{|l|}{$\mathbf{A}$} \\
\hline mean & 0.27 & 2.66 & 0.14 & 0.05 & 2.03 \\
\hline $\min$ & 0.17 & 1.56 & $<0.02$ & $<0.02$ & 1.32 \\
\hline $\max$ & 0.46 & 3.99 & 0.36 & 0.10 & 2.38 \\
\hline \multicolumn{6}{|l|}{ B } \\
\hline mean & 0.23 & 1.05 & 0.05 & 0.03 & 2.40 \\
\hline $\min$ & $<0.02$ & 0.63 & 0.03 & $<0.02$ & 2.19 \\
\hline $\max$ & 0.26 & 1.42 & 0.09 & 0.05 & 2.73 \\
\hline \multicolumn{6}{|l|}{$C$} \\
\hline mean & 0.10 & 3.18 & 0.07 & 0.03 & 4.51 \\
\hline $\min$ & $<0.02$ & 1.43 & $<0.02$ & $<0.02$ & 1.29 \\
\hline $\max$ & 0.27 & 4.02 & 0.12 & 0.05 & 4.78 \\
\hline \multicolumn{6}{|l|}{ D } \\
\hline mean & $<0.02$ & 1.29 & 0.08 & 0.02 & 0.89 \\
\hline $\min$ & $<0.02$ & 0.54 & $<0.02$ & $<0.02$ & 0.32 \\
\hline $\max$ & $<0.02$ & 1.78 & 0.11 & 0.05 & 1.15 \\
\hline
\end{tabular}

The bioavailable content of $\mathrm{Ca}, \mathrm{Mg}, \mathrm{Zn}, \mathrm{Mn}$, and Fe in fresh leaves of Sempervivum tectorum L. is depicted in Table 5.

The concentrations of elements in juice obtained from fresh leaves are presented in Table 6. 
Table 5. Bioavailable content of $\mathrm{Ca}, \mathrm{Mg}, \mathrm{Zn}, \mathrm{Mn}$, and Fe in fresh leaves of Sempervivum tectorum $\mathrm{L}$. as a mean values (RSD for all samples varied between 3-8\%).

\begin{tabular}{cccccc}
\hline & $\begin{array}{c}\mathrm{Ca} \\
\mathbf{g ~ k g}^{\mathbf{1}}\end{array}$ & $\begin{array}{c}\mathbf{M g} \\
\mathbf{g ~ k g}^{-\mathbf{1}}\end{array}$ & $\begin{array}{c}\mathbf{Z n} \\
\mathbf{m g ~ k g}^{-\mathbf{1}}\end{array}$ & $\begin{array}{c}\mathbf{M n} \\
\mathbf{m g ~ k g}\end{array}$ & $\begin{array}{c}\mathbf{F e} \\
\mathbf{m g ~ k g}^{-\mathbf{1}}\end{array}$ \\
\hline $\mathbf{B}$ & 5.07 & 0.40 & 3.55 & 1.97 & 16.5 \\
$\mathbf{C}$ & 2.95 & 0.44 & 3.58 & 9.02 & 20.0 \\
$\mathbf{D}$ & 3.16 & 0.37 & 2.37 & 1.71 & 12.3 \\
\hline
\end{tabular}

Table 6. Element concentrations (mg/L) in fresh juice from Sempervivum tectorum $\mathrm{L}$.

\begin{tabular}{lclc}
\hline Elements & A & Elements & A \\
\hline $\mathrm{K}, \mathrm{mg} \mathrm{L}^{-1}$ & 133 & $\mathrm{Na}, \mathrm{mg} \mathrm{L}^{-1}$ & 0.7 \\
$\mathrm{Ca}, \mathrm{mg} \mathrm{L}^{-1}$ & 561 & $\mathrm{Zn}, \mathrm{mg} \mathrm{L}^{-1}$ & 1.95 \\
$\mathrm{Mg}, \mathrm{mg} \mathrm{L}^{-1}$ & 2845 & $\mathrm{Al}, \mathrm{mg} \mathrm{L}^{-1}$ & 3.45 \\
$\mathrm{Fe}, \mathrm{mg} \mathrm{L}^{-1}$ & 0.07 & $\mathrm{Cu}, \mathrm{mg} \mathrm{L}^{-1}$ & 0.28 \\
$\mathrm{Mn}, \mathrm{mg} \mathrm{L}^{-1}$ & 2.40 & $\mathrm{Cr}, \mathrm{mg} \mathrm{L}^{-1}$ & 0.29 \\
\hline
\end{tabular}

\section{Discussion}

As seen from Table 1, Sempervivum tectorum L. contains an extremely high calcium content, exceeding by between 3-10 times the concentrations of the second highest content element, K. No statistically significant differences were found for the total content of essential elements (except $\mathrm{Ca}$ and $\mathrm{Mn}$ ) in plants from different regions, confirming the biouptake ability of plant toward essential elements [14]. Unexpectedly a higher total content of Ca was observed in rural and urban plants in comparison with plants from fertilized and mountain regions. Significantly higher concentrations of Mn were determined in the plants grown on fertilized soils, which might be explained by the high bioavailable $\mathrm{Mn}$ content in these soils, as the same concentrations were measured in other herbs from the same region. The total content of essential elements presented at lower concentration levels in Sempervivum tectorum L. is close to the content of these elements in other herbs from these regions $[15,16]$.

Table 2 lists the results obtained for some nonessential elements. As can be seen, the plants grown on agricultural (fertilized) soils differed from the others with their higher concentrations of $\mathrm{Al}, \mathrm{Co}$, and $\mathrm{Ba}$. However, only the concentrations of cobalt were surprising, as $\mathrm{Al}$ of such and higher concentrations is found in herbs from this region [15].

Another critical aspect is the good quality control of medicinal herbs, to protect consumers from contamination, as many medicinal herbs and their mixtures can present a health risk due to toxic elements [17].

Toxic element levels in raw plant material or prepared products/extracts/infusions is regulated by documents at global, national, or regional level. Strict control of contaminant levels and their minimization is required by the World Health Organization (WHO) through guidelines such as the good agricultural and collection practices (GACP) for medicinal plants and good manufacturing practices (GMP) for herbal medicines. Maximal values for toxic elements in herbal drugs and extracts have been discussed and compared by several authors [18-20].

According to the World Health Organization, cadmium concentrations and lead in herbal medicines and products are regulated at $0.3 \mathrm{mg} \mathrm{kg}^{-1} \mathrm{Cd}$ and $10.0 \mathrm{mg} \mathrm{kg}^{-1} \mathrm{~Pb}$ [18]. In different countries, the law sets lower limits, and a very good comparison of the various permissible limits is presented by Luo et al. [20]. As shown in Table 3, the concentrations of toxic elements meet the requirements of the WHO, and only in one single case was the cadmium concentration exceeded, for urban soil. Expectedly, the results for elements such as $\mathrm{As}, \mathrm{Cd}$, and $\mathrm{Pb}$ are highest in plants grown on urban soils. Most probably, in this case both soil pollution and aerosol deposition are responsible for the high toxic element content. Although, it is clearly important to harvest medicinal plants from clean sites 
without anthropogenic influences such as mountain regions. A relatively high content was determined for $\mathrm{Ni}$ and $\mathrm{Pb}$ in plants grown on fertilized soils, most likely connected with $\mathrm{Ni}$ and $\mathrm{Pb}$ contamination by the phosphate fertilizers applied.

In this study, sampling for all studied plants and sampling sites was performed in the summer season, with some efforts to use plants in the same vegetation period. Taking into account that Sempervivum tectorum $\mathrm{L}$. is a perennial plant, additional research is required to elucidate any correlation between plant age and chemical element content.

In Table 4, the results found for the operationally defined bioavailable content (see Section 2.3) of $\mathrm{Ca}, \mathrm{Mg}, \mathrm{Zn}, \mathrm{Mn}$, and Fe in fresh leaves of Sempervivum tectorum L. (after two hours of treatment in $\mathrm{pH} 1.0-1.5)$ are depicted. Plants growing on mountains, villages, and fertilized soils were used. The percentage content of bioavailable fraction varied between $4-14 \%$ for all studied essential elements (Table 7). It should be pointed out that the content of $\mathrm{Ca}$ and $\mathrm{Fe}$, which might be accepted as being most responsible for the health functions of Sempervivum tectorum L., is almost constant in the bioavailable fractions from all samples. High concentrations of $\mathrm{Ca}$ in this fraction justify the use of Sempervivum tectorum L. as a national remedy for the treatment of gastric ulcers, possibly because of the beneficial calcification effect.

Table 7. Bioavailable concentrations of $\mathrm{Ca}, \mathrm{Mg}, \mathrm{Zn}, \mathrm{Mn}$, and $\mathrm{Fe}$ as a percentage of total content.

\begin{tabular}{cccccc}
\hline & $\begin{array}{c}\text { Ca } \\
\text { Bioavaible } \\
\text { Fraction, \% }\end{array}$ & $\begin{array}{c}\text { Mg } \\
\text { Bioavaible } \\
\text { Fraction, \% }\end{array}$ & $\begin{array}{c}\text { Zn } \\
\text { Bioavaible } \\
\text { Fraction, \% }\end{array}$ & $\begin{array}{c}\text { Mn } \\
\text { Bioavaible } \\
\text { Fraction, \% }\end{array}$ & $\begin{array}{c}\text { Fe } \\
\text { Bioavaible } \\
\text { Fraction, \% }\end{array}$ \\
\hline B & 4.37 & 3.45 & 4.49 & 6.42 & 4.30 \\
C & 4.46 & 5.63 & 11.7 & 3.30 & 5.59 \\
D & 5.18 & 6.51 & 8.12 & 14.1 & 4.98 \\
\hline
\end{tabular}

Although the concentration of Mn is still highest as a bioavailable concentration, the degree of extraction was significantly lower, most probably depending on the different $\mathrm{Mn}$ species present in the leaves. Therefore, it might be assumed that the Mn bio-uptake would be highest from agricultural (fertilized) soils, most probably because of suitable $\mathrm{pH}$ values.

Determination of elements in juice from fresh leaves. Fresh juice obtained by squeezing leaves from Sempervivum tectorum L. was widely used as folk medicine against ear pain. As shown in Table 6, this effect can most probably be explained by the high $\mathrm{Mg}$ concentrations, analogous to the pharmaceuticals used for external application (Mg-gels or Mg-oils) with anti-inflammatory and regenerative actions and improved blood circulation [21-23]

\section{Conclusions}

The total element contents and the bioavailable fraction of essential elements $\mathrm{Ca}, \mathrm{Mg}$, $\mathrm{Zn}, \mathrm{Mn}$, and Fe were determined in leaves of Sempervivum tectorum $\mathrm{L}$. The control of the quality of medicinal plants used in traditional medicine and pharmacy is an important step for consumer protection from contamination and health risks. The determination of toxic element content in plants grown on different soils clearly shows the contamination of plants from urban soils and plants fertilized with phosphate fertilizers. The high bioavailable concentrations of essential elements could explain the wide use of this plant in folk medicine. For example, the high $\mathrm{Mg}$ content in fresh juice is responsible for its anti-inflammatory action and application as an ear pain reliever. 
Author Contributions: K.N. constructed and conceived the project. G.G. and I.K. designed the study. P.R., S.M., Y.S. and I.Y. performed the study. V.A. and Y.S. analyzed the data. G.G. and I.K. wrote the newspaper. All authors have read and agreed to the published version of the manuscript.

Funding: This research was funded by the Bulgarian Ministry of Education and Science under the National Research Programme "Healthy Foods for a Strong Bio-Economy and Quality of Life" approved by DCM \# 577/17.08.2018.

Institutional Review Board Statement: Not applicable.

Informed Consent Statement: Not applicable.

Data Availability Statement: Datasets from the time of this study are available from the respective author upon reasonable request.

Acknowledgments: Special thanks to Medical University-Varna for the provided financial support for paper publication.

Conflicts of Interest: The authors declare no conflict of interest.

\section{References}

1. Hájek, M.; Hájková, P.; Apostolova, I.; Horsák, M.; Plášek, V.; Shaw, B.; Lazarova, M. Disjunct Occurrences of Plant Species in the Refugial Mires of Bulgaria. Folia Geobot. 2009, 44, 365-386. [CrossRef]

2. Parolo, G.; Abeli, T.; Rossi, G.; Dowgiallo, G.; Matthies, D. Biological flora of Central Europe: Leucojum aestivum L. Perspect. Plant Ecol. Evol. Syst. 2011, 13, 319-330. [CrossRef]

3. Evstatieva, L.; Hardalova, R.; Stoyanova, K. Medicinal plants in Bulgaria: Diversity, legislation, conservation and trade. Phytol. Balc. 2007, 13, 415-427.

4. Blázovics, A.; Fehér, J.; Fehér, E.; Kery, A.; Petri, G. Liver protecting and lipid lowering effects of Sempervivum tectorum extract in the rat. Phytother. Res. 1993, 7, 98-100. [CrossRef]

5. Šentjurc, M.; Nemec, M.; Connor, H.D.; Abram, V. Antioxidant activity of Sempervivum tectorum and its components. J. Agric. Food Chem. 2003, 51, 2766-2771. [CrossRef] [PubMed]

6. Cattaneo, F.; De Marino, S.; Parisi, M.; Festa, C.; Castaldo, M.; Finamore, C.; Duraturo, F.; Zollo, C.; Ammendola, R.; Zollo, F.; et al. Wound healing activity and phytochemical screening of purified fractions of Sempervivum tectorum L. leaves on HCT 116 . Phytochem. Anal. 2019, 30, 524-534. [CrossRef]

7. Szentmihályi, K.; Fehér, E.; Vinkler, P.; Kéry, Á.; Blázovics, A. Metabolic Alterations of Toxic and Nonessential Elements by the Treatment of Sempervivum tectorum Extract in a Hyperlipidemic Rat Model. Toxicol. Pathol. 2004, 32, 50-57. [CrossRef] [PubMed]

8. Muselin, F.; Trif, A.; Stana, L.G.; Romeo, C.T.; Corina, G.; Ioan, M.; Dumitrescu, E. Protective Effects of Aqueous Extract of Sempervivum tectorum L. (Crassulaceae) on Aluminium-Induced Oxidative Stress in Rat Blood. Trop. J. Pharm. Res. 2014, 13, 179-184.

9. Stojković, D.; Barros, L.; Petrović, J.; Glamoclija, J.; Santos-Buelga, C.; Ferreira, I.; Soković, M. Ethnopharmacological uses of Sempervivum tectorum L. in southern Serbia: Scientific confirmation for the use against otitis linked bacteria. J. Ethnopharmacol. 2015, 176, 297-304. [CrossRef]

10. Alberti, Á.; Béni, S.; Lackó, E.; Riba, P.; Al-Khrasani, M.; Kery, A. Characterization of phenolic compounds and antinociceptive activity of Sempervivum tectorum L. leaf juice. J. Pharm. Biomed. Anal. 2012, 70, 143-150. [CrossRef]

11. Abram, V.; Donko, M. Tentative identification of polyphenols in Sempervivum tectorum and assessment of the antimicrobial activity of Sempervivum L. J. Agric. Food Chem. 1999, 47, 485-489. [CrossRef]

12. Gentscheva, G.; Karadjova, I.; Buhalova, D.; Predoeva, A.; Nikolova, K.; Aleksieva, I. Determination of essential and toxic elements in berries from Bulgaria (Plovdiv region). C. R. Acad. Bulg. Sci. 2014, 67, 1241-1248.

13. Graham, R.D.; Stangoulis, J.C.R. Trace Element Uptake and Distribution in Plants. J. Nutr. 2003, 133, 1502S-1505S. [CrossRef] [PubMed]

14. Morgan, J.B.; Connolly, E.L. Plant-Soil Interactions: Nutrient Uptake. Nat. Educ. Knowl. 2013, 4, 2.

15. Gentscheva, G.; Stafilov, T.; Ivanova, E. Determination of some essential and toxic elements in herbs from Bulgaria and Macedonia using atomic spectrometry. Eurasian J. Anal. Chem. 2010, 5, 104-111.

16. Mihaljev, Z.; Zivkov-Balos, M.; Cupić, Z.; Jaksić, S. Levels of some microelements and essential heavy metals in herbal teas in Serbia. Acta Pol. Pharm. 2014, 71, 385-391.

17. Pavlova, D.; Karadjova, I. Toxic Element Profiles in Selected Medicinal Plants Growing on Serpentines in Bulgaria. Biol. Trace Elem. Res. 2013, 156, 288-297. [CrossRef] [PubMed]

18. World Health Organization (WHO). Guidelines for Assessing the Quality of Herbal Medicines with Reference to Contaminants and Residue; WHO: Geneva, Switzerland, 2007.

19. Gasser, U.; Klier, B.; Kuhn, A.; Steinhoff, B. Current findings on the heavy metal content in herbal drugs. Pharmeuropa Sci. Notes 2009, 1, 37-49. 
20. Luo, L.; Wang, B.; Jiang, J.; Fitzgerald, M.; Huang, Q.; Yu, Z.; Li, H.; Zhang, J.; Wei, J.; Yang, C.; et al. Heavy Metal Contaminations in Herbal Medicines: Determination, Comprehensive Risk Assessments, and Solutions. Front. Pharmacol. 2020, $11,595335$. [CrossRef]

21. Zhang, H.; Zhang, Q.; Cai, Q.; Luo, Q.; Li, X.; Li, X.; Zhang, K.; Zhu, W. In-reactor engineering of bioactive aliphatic polyesters via magnesium-catalyzed polycondensation for guided tissue regeneration. Chem. Eng. J. 2021, 424, 130432. [CrossRef]

22. Dudina, M.O.; Suslova, I.R.; Khalzova, M.S.; Dergunova, J.V.; Kogan, E.A.; Roshchin, D.A.; Samyshina, E.A.; Morozov, M.A.; Dydykin, S.S. Molecular and cellular mechanisms of acute cytotoxic liver damage as potential biological targets for magnesiumcontaining cell-protective drug. Res. Results Pharmacol. 2018, 4, 9-15. [CrossRef]

23. Labuschagné, F.J.W.J.; Wiid, A.; Venter, H.P.; Gevers, B.R.; Leuteritz, A. Green synthesis of hydrotalcite from untreated magnesium oxide and aluminum hydroxide. Green Chem. Lett. Rev. 2018, 11, 18-28. [CrossRef] 